\section{Susanne Ramadan Shunnaq}

Sultan Qaboos University, Oman

Yarmouk University, Jordan

Adel Abu Radwan

Sultan Qaboos University, Oman

\section{Hassan Shuqair}

Sultan Qaboos University, Oman
2020, Vol. 17 (2), 257-278(284) revije.ff.uni-lj.si/elope

https://doi.org/10.4312/elope.17.2.257-278

UDC: 81 '373.612.2=111=411.21:342.849.2(73)

\title{
Problems in Translating Metaphors in Political Campaign Speeches: A Descriptive-Analytical Study
}

\section{ABSTRACT}

This study examines Sultan Qaboos University senior translation students' renditions of metaphors taken from speeches delivered as part of the 2016 US presidential election campaign. An explanatory mixed-methods approach is used to determine, firstly, students' recognition of the metaphor as a construct; secondly, their translation of identified metaphors and the ensuing difficulties they encountered owing to linguistic, rhetorical, and/or cultural considerations; and finally the strategies they adopted to overcome these difficulties. The findings reveal that the students encountered difficulties recognising certain metaphors in the English texts (STs) and faced considerable challenges in translating them appropriately into the target language (TL), which is Arabic. The study concludes with recommendations for translation teachers and translator trainers.

Keywords: English-Arabic translation, metaphor, political speech, rhetoric

\section{Težave pri prevajanju metafor $\mathbf{v}$ govorih politične kampanje: Opisno-analitična študija}

POVZETEK

Študija preučuje prevode metafor iz govorov v ameriški predsedniški volilni kampanji leta 2016, kot so jih prevedli študenti prevajalstva na Univerzi sultana Kabusa. Uporabljamo pojasnjevalni pristop mešanih metod, s katerim ugotavljamo, kako študentje prepoznajo metaforo kot konstrukt, kako prevajajo prepoznane metafore, kakšne prevajalske težave imajo zaradi jezikovnih, retoričnih in/ali kulturnih vidikov in kakšne strategije uporabljajo za premagovanje teh težav. Ugotovitve razkrivajo, da se študentje srečujejo s težavami pri prepoznavanju nekaterih metafor $\mathrm{v}$ angleških besedilih in se soočajo s precejšnjimi izzivi pri ustreznem prevajanju v ciljni jezik, ki je arabščina.

Ključne besede: prevajanje iz angleščine v arabščino, metafora, politični govor, retorika 
"Know a man by his metaphors."

John Connolly, The Wolf in Winter

\section{Introduction}

The use of rhetoric in political speeches has long been an essential part of persuasive discourse used to achieve certain effects, increase interest, and influence public opinion. The US presidential election campaign speeches of 2016 are no exception, as they draw heavily on rhetorical devices such as metaphor to achieve certain desired communicative goals. Most politicians are aware of the profound role rhetoric plays in the effectiveness of their speeches; therefore, many craft their political addresses carefully, since what they say is usually scrutinised by a wide audience.

Translation of speeches rich in metaphors often poses challenges to translators, since metaphors go beyond the literal meaning of words to give readers a more complex view of the topic under discussion, and insights into different cultural and social aspects of both the source language (SL) and the target language (TL). This requires translators to have deep knowledge of the cultural and linguistic aspects of the SL, and to be especially careful in deciphering the meanings embedded in the metaphorical structures to render them accurately into the TL. To achieve this, translators need to be equipped with "an adequately differentiated linguistic, extra-linguistic, and sociocultural knowledge in two languages" (Wilss 1996, 3). This implies that linguistic knowledge of the two languages by itself does not usually suffice, as the translation process involves more than simply a transfer of meaning between the SL and the TL. Proper rendition of the source text (ST) into the TL requires the translator to possess both a high linguistic competency in both languages and vast knowledge of their crosscultural semantic and pragmatic aspects. The problem of transferring metaphors into Arabic is further compounded by the fact that Arabic and English belong to two language families with entirely different linguistic systems and cultural, social and historical contexts. Therefore, many metaphors in the SL may not be recognised at all or are entirely misunderstood and thus mistranslated.

Metaphors are frequently used in political discourse for different communicative purposes in addressing large heterogeneous audiences. The translation of metaphor can be problematic, since linguistic and semantic equivalence may not always be achieved. Research on the translation of figures of speech in English political discourse is scarce. One recent study by Ramadan Shunnaq, Shuqair, and Abu Radwan (2018) focuses on the English-Arabic translation of rhetorical devices, but does not explore metaphor. There is an apparent paucity in the investigation of metaphor translation from English into Arabic (see Aldanani 2018; AlHasnawi 2007; Jaber 2008; Ghazala 2012; Ateeg and Al-Tamimi 2014; Nader 2014; Mansoor 2017). Hence, the current study is an important contribution to the available literature in this area as it explores English-Arabic translation of metaphors in political discourse.

This study seeks to fill in this gap by examining the main challenges that Arab translation students encounter in recognising, understanding, and properly rendering metaphors used in political discourse from English into Arabic, and identifying the strategies they utilise 
to overcome these problems. The study analyses Sultan Qaboos University (SQU) senior translation students' renditions of metaphorical structures used by Barack Obama, Hillary Clinton, and Donald Trump in the 2016 US presidential campaign speeches. An explanatory mixed-method approach is used to analyse the collected data. In the first phase of the study, the students were asked to identify the metaphorical structures in excerpts from the campaign speeches to measure the frequency of their recognition of these structures. Then, they were asked to translate the metaphorical structures to measure their understanding and proper rendition of the metaphors. The results of this study contribute to a better understanding of the nature of the difficulties involved in the recognition of metaphors present in English political discourse and their translation into Arabic. Based on the findings, the study provides several recommendations for translation teachers and students interested in metaphorical structures.

\section{Previous Studies on the Translation of Metaphors}

Metaphors can pose a serious challenge to translators. Some theorists and critics such as Dagut (1976), Van den Broeck (1981), and Mason (1982) have argued that some metaphorical expressions cannot at all be translated or are not directly translatable, and the issue has triggered heated debates among linguists and theorists for many years. Newmark (1988a, 104) mentions that "[w]hilst the central problem of translation is the overall choice of translation method for a text, the most important particular problem is the translation of metaphor." Shunnaq (1993) discusses the translation of emotive expressions, which include metaphors, and demonstrates that translating them is a challenging task because their connotative meanings are often difficult to convey. He concludes that complete congruence in translating Arabic emotive expressions is difficult to achieve; thus, he suggests using paraphrasing, footnotes, exemplifications, and glossaries to aid in the translation process to achieve the desired, optimal and precise translation. Farhan and Taha (2006) concur with Shunnaq, and stress that translating emotive or expressive texts from English into Arabic is not an easy task. They affirm that achieving congruency in translating such texts can be rather difficult. Al-Harahsheh (2013) also examines the translatability of emotive expressions in political discourse from Arabic into English, and concludes that the translation of figures of speech including metaphors can be problematic, because the rendered translation often loses its flavour of emotiveness.

Up until recently, metaphor has been traditionally viewed as a stylistic device; however, linguists have held long debates about whether to consider metaphor as a linguistic or rhetorical device or a conceptual process. Linguists who believe that metaphor involves cognitive processes and conceptual mapping challenge the former view by explaining that human thinking and communication rely heavily on our conceptual understanding of the world around us (Lakoff and Johnson 1999). Furthermore, a central argument within cognitive linguistics is that everyday communication relies heavily on concepts structured by metaphor. Likewise, Kövecses (2015, ix) acknowledges that "the human conceptual system is heavily metaphorical in nature and that we use metaphors spontaneously and with ease in the course of everyday communication". According to the Conceptual Metaphor Theory (CMT) that started in the 1980s, metaphor plays a structural role in the arrangement and processing of conceptual knowledge and the structuring and restructuring of reality (Kövecses 2010). The literature generally defines a conceptual or cognitive metaphor as a set of correspondences or mappings 
that enable us to understand one idea or conceptual domain (source domain) in terms of another (the target domain). The source domain is the concrete or physical domain, and the target domain is the abstract one. Kövecses (2016) maintains that the application of a source domain to a particular target domain contributes to the construction of a particular reality that may affect our views of life or even create new realities for us.

Mandelblit $(1995,483)$ also adopts a cognitive view of the translation of metaphor, which is the basis of her Cognitive Translation Hypothesis - she argues that the difficulty in metaphor translation "resides in the use of different metaphorical mappings between the source language (SL) and the target language (TL) to express the same idea". As such, the translation of metaphors involves not only the transfer of a certain rhetorical style in a certain language to another, but also the transfer of a cognitive construct that represents how people conceptualise their experiences. She describes the translation process as "not only a transfer process from on language to another but also a transfer from one way of conceptualizing the world into another" $(1995,483)$. Mandelblit proposes two schemes for the translation of metaphor: (1) similar mapping conditions when the metaphors of the two languages do not require a conceptual shift as ideas are expressed by identical expressions in both languages, and (2) different mapping conditions in case there is a conceptual shift between the metaphors of the two languages as no equivalence exists in the TL. In such cases, a degree of equivalence needs to be established between the ST and the target text (TT). Thus, when the two languages belong to the first scheme, the translator's task becomes simple, as he only has to choose an appropriate TL metaphor; however, in the second scheme, the task becomes more complicated. Al-Hasnawi (2007) explains the source of difficulty involved in this case by stating that the translator undertakes the task of creating the proper conceptual mapping for the TL reader. To overcome this difficulty, Mandelblit (1995), like Shunnaq (1993), suggests using paraphrasing, footnotes, explanation or total deletion of the metaphor.

The more recent metaphor theory tries to look at ways to bridge the divide between discourse and cognition-oriented approaches or the cognitive-science and social-science perspectives. However, it seems that the divide between discourse- and cognition-oriented approaches is likely to linger. Despite this, there are attempts to unite the field through interdisciplinary collaboration. For instance, Hampe (2017) tries to take multiple perspectives into consideration to create a new research approach with multiple methodologies.

As for metaphor classification, Dagut (1976) classifies metaphors into several categories such as dead, stock, recent, and lexicalised metaphors. Dead metaphors are also known as frozen, fossilised, or lexicalised metaphors. Dickins $(2005,231)$ defines lexicalised metaphors as "uses of language which are recognizably metaphorical, but whose meaning in a particular language is relatively clearly fixed". An example of this type is the use of the word 'rat' to mean 'snitch'. Other examples of this type are 'bottleneck' and 'roadblock'. This type of metaphor has lost its literal meaning and is part of the daily lexicon of users. Newmark (1982) further divides this type into opaque and transparent dead metaphors. The former is no longer recognised as a metaphor because the original meaning of its components has disappeared, as in 'news magazine', since a magazine was originally a place of storage. Others may have foreign assets borrowed from other languages such as Latin or Greek. The latter, according to Paprotté 
and Dirven (1985, 299-301) has three types: 1) words like 'reflect' for 'think' and 'shine' for 'excel', 2) metonym or one-word metaphor which retains its denotative meaning as can be found in technical terms such as 'fin' and 'nut', 3) non-technical words that have both concrete and figurative senses such as 'head', 'foot', 'arm', 'food', 'deep', 'broad', 'bottom' as in 'the foot of the mountain' or 'the bottom of a hill'. Stock metaphors describe concrete or abstract concepts and have an aesthetic function. Examples are 'it's raining cats and dogs', 'shed light on something', and 'keep the pot boiling'. According to Dickins (2005, 237), stock metaphors are "established metaphors", and are categorised as lexicalised metaphors. They are, however, not deadened by overuse (Bojović 2014, 76).

Another category is non-lexicalised metaphors, where the "metaphorical meaning is not clearly fixed, but will vary from context to context, and typically has to be worked out by the reader on particular occasions" (Dickins 2005, 232). Recent and original metaphors are two types of non-lexicalised metaphors. Newmark (1988a, 111-12) considered recent metaphors as metaphorical neologisms such as 'dog' that may receive positive or negative connotations in different contexts, or like something that is 'in' meaning fashionable and 'walkman' for a portable music player (see Newmark 1988a, 150 for types of neologisms). These metaphors are usually anonymous and widespread. Original metaphors are those that are created by an author and are used on a more individual basis.

As discussions concerning the classification of metaphors continue, so have critics, linguists and theorists continued to debate the best approaches to translating metaphors. Gonzálvez-García, Cervel, and Hernández $(2013,265-82)$ list critical opinions on the translation of metaphors, and discuss recent developments in this field until 2010. Dickins, Hervey, and Higgins (2002, 150-55) for instance, suggest techniques for the translation of stock metaphors. They propose that when translating these translators need to take decisions regarding the components of the metaphor: the topic, vehicle, and grounds or the metaphor $(2002,148)$. An example of this is 'the eye of the needle', where the opening in the needle is the 'topic' or also known as 'tenor' (i.e. the referent or object) which is likened to an 'eye' (vehicle or image that is the metaphor itself). The opening in the needle is the 'grounds' that shows in what particular aspects the object and image are similar. Further, the authors suggest that translators have the following options when rendering established metaphors: (1) retention of metaphor by having the same vehicle in the target language, (2) replacement of the stock metaphor by a stock metaphor in the TL with a different vehicle, (3) rendition of the stock metaphor into a simile in the TL, or (4) a reduction of the metaphor to grounds. Regarding recent metaphors, the main strategy is to find an equivalent form in the target language.

In the translation of non-lexicalised metaphors, translators have different choices such as retention of the metaphor with the same vehicle in the target language, making some necessary changes without altering the metaphor while rendering the context in which it occurs more acceptable in the TL, replacement of the metaphor in the SL with a nonlexicalised metaphor in the TL with a different vehicle, and finally replacing the metaphor with a stock metaphor in the TL.

To simplify matters, the literature on the translation methods of metaphors reveals that authors for the most part agree on four common strategies: 1) direct translation of metaphor, 2) partial 
replacement of metaphor to suit the TL audience and culture, 3) replacement of metaphor by a pragmatic TL alternative metaphor, and 4) replacement of the SL metaphor with a TL non-metaphor. Research on metaphor has so far illustrated the challenges metaphor can cause in a translation processes, especially when the source and target languages are linguistically and culturally different. For this reason, the current study will describe the difficulties that translation students encountered in recognising and translating metaphors used in political discourse. Further, the researchers will draw on the above frameworks in their analysis of the strategies that student translators utilised in the translation of the different types of metaphors.

\section{The Study}

\subsection{Participants}

The participants in this study were 20 senior students registered in the BA program in Translation in the Department of English Language and Literature at Sultan Qaboos University (SQU). Admission to the program is contingent upon students achieving high grades in both Arabic and English introductory courses, with only the top ten applicants admitted every semester. The program continues for five years, where the first is devoted completely to intensive language training. During the course of their study in the program, the students take several introductory and specialised translation courses such as literary translation, media translation, business and commercial translation, legal and documentary translation, translation critique and translation studies. The research sample consists of students enrolled in two translation courses in the autumn and spring semesters of 2018.

\subsection{Data}

Part of the course requirements for advanced translation students is the translation of journalistic and political texts, including public speeches, from English to Arabic. Since the study sample was senior students in the translation program who needed to practice the translation of political discourse and style, they were given texts that demanded careful consideration. Because recognising and understanding metaphors and subsequently deciding on the most suitable translation strategy are among the most challenging processes in translation, the researchers decided to give students translation tasks that combine political discourse and figurative language. Owing to Lakoffs assertion that implicit metaphors play a powerful role in political discourse (Lakoff 2002, 2008), and since political campaigns are fertile grounds for the usage of metaphors and the US presidential elections always make headlines in international media, the researchers opted for a selection of campaign speeches delivered by Obama, Clinton, and Trump during the 2016 US presidential campaign. At the time, Obama was nearing the end of his second presidential term and was not a nominee, but he was actively involved in Hillary Clinton's campaign. He gave a number of speeches in her support to help restore his party's strength and secure his legacy. The researchers selected nine speeches that were delivered during the campaign. These texts were given to the students who were instructed to underline the metaphors they recognised in each text in order to test their metaphor identification skills. The students identified a number of metaphors in the speeches, but missed others altogether. Based on the results of this task and the analysis thereof, the researchers singled out the passages that most clearly showed the extent of students' ability to 
identify and translate particular metaphors. The most pertinent examples in each speech were chosen to illustrate the difficulties students encountered in the translation of different types of metaphor. Those metaphors which all students failed to identify were not included in this study. Then, following this task, the students were given another copy of the same texts with select metaphors underlined and were asked to translate the passages containing them, paying special attention to the underlined metaphors. Since translation speed was not measured, no time restrictions were imposed on the translation task.

To confirm the researchers' identification of metaphors in the texts of the speeches, copies of the selected speeches were given to two colleagues in the Department of English for metaphor recognition. Interrater reliability was around $95 \%$. The researchers then categorised the metaphors into three categories, A, B, and C, as explained below. Student translations of the metaphors were also presented to two colleagues with experience of translation to judge the quality and acceptability of the renditions. The inter-rater reliability here was $92 \%$.

\section{Findings and Discussion}

\subsection{Recognition Task}

Analysis of students' responses to the recognition task reveals that a reasonable number were able to identify the majority of metaphors with very few exceptions, as shown in Table (1) below. As can be noticed, most students failed to identify metaphor \#2. In other cases (M4, M5, M8), students also faced substantial recognition problems. The reasons for such difficulties are limited rhetorical and figurative competence, limited lexical knowledge with regard to specialised texts, and weak communicative competence in the SL. Based on this, it is assumed that the difficulties that students encounter in the translation of the metaphors, as will be explained below, cannot be attributed to their failure to recognise the metaphors, since they many of them managed to identify them.

TABLE 1. Students' recognition of metaphor.

\begin{tabular}{|l|c|c|c|c|c|c|c|c|c|}
\hline Category & \multicolumn{4}{|c|}{ A } & \multicolumn{3}{c|}{ B } & \multicolumn{3}{c|}{ C } \\
\hline Metaphor (M) & M1 & M2 & M3 & M4 & M5 & M6 & M7 & M8 & M9 \\
\hline Number of students & 18 & 2 & 17 & 12 & 14 & 19 & 20 & 13 & 19 \\
\hline $\begin{array}{l}\text { Percentage of students } \\
\text { who recognised the } \\
\text { metaphor (\%) }\end{array}$ & 90 & 10 & 85 & 60 & 70 & 95 & 100 & 65 & 95 \\
\hline
\end{tabular}

\subsection{Translation Task}

Students' translations of each metaphor were analysed for accuracy of the translation, problems faced with the translation of metaphorical structures, and the strategies used to overcome these problems. As mentioned above, the classification and analysis of metaphors in this study are primarily informed by Newmark's (1988b) seminal work elaborated on by Dickins, Hervey, and Higgins (2002). The nine metaphors used in this task were classified into three categories according to the degree of transfer and equivalence students were able 
to achieve. The first category of metaphors (M1 to M4) illustrates how students were able to align metaphor segments in the source text (ST) and the target text (TT) to produce an intact transfer. In all these cases, the target language has equivalent or near equivalent forms and students were able to align the topic, vehicle, and grounds between the ST and the TT. Category B (M5 and M6), students were able to produce a partial transfer as only one or two components of the metaphor were present in their translations. As for the remaining metaphors, (M7-M9), representing Category $\mathrm{C}$, students were unable to transfer the components of the metaphor from the SL to the TL. Students' translations of the metaphors in each of these categories revealed that students faced variable levels of difficulty in their efforts to render them properly, as explained in detail below.

\subsubsection{Category A: Direct Transfer of the Topic, Vehicle, and Grounds}

In the translation of metaphors in this category, students were able to produce renditions that contained all three elements of the metaphors (topic, vehicle, and grounds). Hence, many were able to preserve the components of the metaphor in the TL by adopting different strategies in their renditions based on several factors, such as availability of an equivalent metaphor in the TL, the cultural reference of the metaphor, and idiomaticity of the rendered metaphor. Therefore, when students were aware of a corresponding or equivalent metaphor in the TL, they adopted a direct transfer strategy and were thus able to preserve the elements of the metaphor. This is evident in the translation of (M1) below.

M1. "She has been accused of everything you can imagine-and some things that you cannot. But she knows that's what happens when you're under a microscope for 40 years."

(Obama's Democratic National Convention speech, July 27th, 2016)

In the translation of this conventionalised transparent metaphor, the majority of the participants managed to produce a corresponding metaphor in the TL by using the strategy of literal translation. Students' attempts to translate his metaphorical structure in English produced the following with the literal translations provided between brackets:

1. 'eindama takun taht almijhar ('when you are under the microscope')

2. 'eindama takun taht muraqaba shadiida ('when you are being heavily monitored')

3. 'eindama yusallit 'ealayka aldaw ('when you come under the spotlight')

4. 'eindama takunn mahatt al'anzar ('when you are the focus of attention')

In fact, eleven students translated the SL metaphor into 'eindama takuun tabt almijhar ('when you are under the microscope'), thereby preserving the SL metaphor in the TL without change. This rendition maintained both the metaphorical nature of the original text and the ideational content of the metaphor. A number of other students replaced the metaphor with an idiom that is a metaphor, but they used a different vehicle (Dickins, Hervey, and Higgins, 2002). For example, four students rendered the metaphor as 'eindama yusallit 'ealayka aldaw ('when you come under the spotlight'). The topic and grounds are retained, but the vehicle has been replaced by one that offers an idiomatic structure in Arabic. Four more students decided 
that the best translation was 'eindama takuun mahatt al'anzar ('when you are the focus of attention'), where the students also replaced the vehicle with a metaphorical idiomatic phrase commonly used in Arabic. Only one student resorted to deleting the metaphor entirely, thus providing an incomplete, low-quality translation. Overall, the majority of the students were able to present acceptable renditions of the metaphorical structure that either maintained the three components of the metaphor (direct transfer) or decided to use a different vehicle to produce an idiomatic structure in the TL. The issue here was the choice of the appropriate translation strategy and finding a stylistically acceptable rendition in the TL.

The next metaphor in this category, (M2), represents a very popular environmental term in both the SL and TL that $90 \%$ of the students failed to recognise as a metaphor. It went undetected due to its conventionalisation.

M2. "Meanwhile, we doubled our production of clean energy; we become the world's leader in fighting against climate change [...] None of that would have happened if it weren't for America's greatest asset."

(Obama at a Hillary Clinton rally in Jacksonville, Florida, November 3rd, 2016)

The metaphorical vehicle of 'clean' vs. 'dirty energy' lies at the core of the rhetorical strategy used by Obama to underscore the seriousness of climate change and the actions that have been taken to combat it. Applying Newmark's classification of metaphors (1988b), this type can be classified as a cliché metaphor. Cliché metaphors stand between dead metaphors and standard or stock metaphors and can appear as figurative adjective + literal noun. The students faced a serious problem in the identification of this metaphor. The problem stems from the fact that this metaphor is no longer recognisable as such, since it has been "naturalised" or "normativised" owing to its frequent daily use (Onuf 2013, 46). Despite the fact that the majority of students failed to identify this recent metaphor, nearly all produced a correct equivalent metaphor in Arabic, which is alttaqa alnazifa ('clean energy'). Only two students rendered it as alttaqa almutajadida ('renewable energy') and alttaqa almustadama ('sustainable energy'); they apparently were not aware of the differences in meaning. The variations in students' translations were mainly in the use of tense and in the use of prepositions used in the sentence containing the metaphor:

1. da'eafna intaajana min alttaaqa alnaziifa ('we doubled our production of clean energy')

2. nuda eif intaajina min alttadqa almustaadama ('we double our production of sustainable energy')

3. da'eafna intaajana lilttaaqa alnaziifa ('we doubled our production for clean energy')

4. da' eafna min 'intaj alttaaqa alnaziifa ('we doubled the production of clean energy')

5. qumna bimuda' eafat muntij alttaaqa alnaziifa ('we did double the product of clean energy')

6. qumna bimuda'afat intajina lilttaqa almutajaddida ('we did double our production of renewable energy') 
The translation in \#3 is the most accurate rendering of the SL text. It retains the pronoun 'our' in 'our production' as the na in intajina. The translation also preserves the verb 'doubled' by using da' eafna instead of qumna bimuda'afat as in \#6. The difference between \#3 and \#6 is mainly in the use of verbs, but both cases are linguistically acceptable renditions into Arabic as they preserve all elements of the SL structure. The main problem the students faced here was not the direct translation of the metaphor, since the same metaphor is used in the TL, but rather trying to produce a linguistically accurate translation with an acceptable structure for the TL readership.

The next metaphor, (M3), represents a very popular metaphor in Arabic; hence, $85 \%$ of the student translators were able to identify it.

M3. "We are going to work with all of our students who are drowning in debt to take the pressure off these young people just starting out in their adult lives."

(Trump's address accepting the Presidential Nomination at the Republican National Convention in Cleveland, Ohio, July 21, 2016 where he pledged to reform the country and enforce the laws of the United States)

Most students translated this conceptual metaphor correctly into the TL with minor variations in their translations related to the building blocks of the sentence and verb tense. The major problem here for students was producing the correct linguistic and stylistic rendition of the sentence structure. Thirteen students chose to translate it as tullaabuna alghariquun fi alduyuun (literally: 'our students drowning in the debts') with the prepositional phrase (literally: 'in the debts') after it. This structure in the TL uses alghariquun as an adjectival form or an attribute qualifying tullabuna ('our students'). Four more students chose to use a relative clause to express the metaphorical drowning instead of a single word attribute: tullabuna aladhin yaghraqun $f$ alduyuun ('our students who are drowning in the debt') followed by the prepositional phrase that completes the meaning of the sentence (silat-ul-mawsuul). One student removed the metaphor entirely. The remaining two student translators produced the following renditions:

1. talamiidhuna aladhiin gharaquu fi bahr duyunihim

('our students who drowned in the sea of their debts')

2. takhlis tullabina min duyunibim allaty aghraqathum ('we rid our students of their debts which drowned them')

In all of these translations, except for the one where the student removed the entire metaphor, all three elements of the metaphor are maintained without losing the intended meaning, and thus this is a clear example of an intact transfer. In \# 1 above, the student added the word $b a b r$ ('sea') to the construct to make the metaphor even more explicit. In addition, the student mistakenly used the past tense (gharaqun 'they drowned'). In \#2, the student decided to move emphasis from drowning to the debts that are causing drowning, hence qualifying 'debts' with a relative clause to stress 'drowning'. The researchers decided that the best translation would have been tullabuna aladhin yaghraqun fi duyuunin. The next example (M4) is one which caused students significant difficulties in translation. 
M4. "You cannot achieve peace if terrorists are treated as martyrs. Glorifying terrorists is a tremendous barrier to peace. It is a horrible, horrible way to think it's a barrier that can't be broken."

(Trump's speech at AIPAC, March 21st, 2016, discussing relations between the US and Israel and criticizing the culture of hatred that has been permeating in Palestine against Israel)

This type of metaphor is conceptual and evaluative in nature, and comes from the source domain 'building'. In this example, the word 'barrier' denotes a negative evaluation, and thus a positive evaluation is sought by its removal. Students' translations of this conceptual metaphor show that a good number of them were able to use an acceptable corresponding collocational structure in Arabic, in which they preserved the metaphor and all of its elements. Seven students translated it correctly producing a translation of the metaphorical structure which represents an acceptable collocational pattern in Arabic, namely tamjiid alirhabiiyn yushakkil 'ayqaan fi tariiq alsalaam ('glorifying terrorists forms an obstacle in the path of peace'). Four students translated the metaphor literally, rendering it as tamjiid al'irhabiiyn 'ayiq hayil 'amam alsalaam ('glorifying terrorists is a tremendous obstacle in front of peace'), and four others decided to use hajz ('barrier') instead of 'ayiq ('obstacle') rendering it as t'aezim al'irhabiiyn ma hu 'iilla hajz hayl fi' ihlal alsalaam ('glorifying terrorists is just a tremendous barrier to achieving peace') or 'amam alsalaam ('in front of peace'). These eight renditions do not match the acceptable collocational patterns in Arabic. The rest of the students translated it as follows:

1. tabjiil al'irhabiiyn yu 'eadl yumaththil 'aeyqan kbyyran liirsa' alsalaam ('venerating terrorists is considered/presents an obstacle in establishing peace')

2. tamjiid al'irhabiiyn hu al 'ayiq al'akbar aldhy yahullu duna tahqiiq alsalaam ('glorifying terrorists is the biggest obstacle to achieving peace')

3. tamjiid al'irhabiiyn hu 'aeyiq dhakhm 'amama 'amaliyat sunea' alsalaam ('glorifying terrorists is a huge obstacle to the peace making process')

We can notice variations in word choice such as tamjiid or tabjiil or t'aeziim for 'glorifying', which show that the students had problems with refining their translations when it came to word choice. This does not reduce the quality of the translations significantly, despite the fact that these small variations in meaning affect their accuracy. Translation \#1 above is an unacceptable unidiomatic structure in Arabic that is linguistically incorrect. Translation \#2 also preserves the metaphor and its translated version is structurally acceptable in Arabic, but is an inaccurate rendition of the SL text. In \#3, the student opted to add another metaphor to the structure, 'amalayat sunea ' alsalaam ('the process of making peace'), which adds meaning to the original metaphor in the SL. This is a possible translation strategy, but creates a translation that does not render the style and meaning of the SL metaphoric structure accurately. The main problem students faced in the translation of metaphor M4 was not the preservation of the SL metaphor, but finding an appropriate idiomatic rendition in the TL that would be accurate and faithful to the ST. 


\subsubsection{Category B: Partial Transfer of Topic, Vehicle and Grounds}

This category of metaphors represents cases where only one or two components of the SL metaphor are represented in the students' translations. The metaphors in this category are complicated ones and caused students some challenges in translating them properly.

M5. "I've met Sarah's beautiful family. But to this administration, their amazing daughter was just one more American life that wasn't worth protecting. One more child to sacrifice on the altar of open borders."

(Donald Trump's nomination acceptance speech at the Republican National Convention, July 21st, 2016)

Donald Trump here refers to 21-year old Sarah Root, who was killed in a motor vehicular homicide that involved an illegal immigrant from Latin America. Trump creates a metaphor with religious connotations with which he tries to persuade his religiously conservative audience that immigration policies need to change. The "open border" policies, i.e. not enough restrictions on immigration to America, are compared to an altar on which Americans get sacrificed.

In this example, twelve students produced a translation that maintained the structure and nature of the metaphor by creating a corresponding new metaphor madhbah alhuduud, ('the border's altar') in analogy with an existing and commonly used metaphor in Arabic madhbah alhuriya ('the freedom's altar'). Although this translation preserves the three components of the metaphor in the TT, the expression has never been used in any known Arabic political discourse to date. A better and more acceptable translation would have been medhbah alhijra ghayr alshr' eyah ('the altar of illegal immigration') that would have conveyed the issue behind Sarah's death more clearly. Two students translated the metaphor as dhariih alhudund almaftuha ('tomb of the open borders'). As is the case with the previous translation above, it is not used in the TL and its meaning would not be comprehensible in Arabic. The vehicle dharih ('tomb') combined with alhuduud almaftuha ('the open borders') does also not convey the meaning of the ST metaphor. Since there is no equivalent metaphor in Arabic, direct translation is not the correct approach here. Students could have opted for substituting the ST metaphor for one with a different vehicle, but corresponding in meaning with the SL metaphor (van den Broeck 1981, 77). Thus, the metaphors created by the students would not strike a chord with Arabic readers, and would also lead to a loss of meaning of the original metaphor. The rest of the students produced the following translations:

1. tiflah 'ukhra tudhahi biha fi hykal alhuduud almaftuha ('another girl child is being sacrificed at the temple of open boarders')

2. tifl aakhar sayatimu altadhia bihi fi medhbah alkaniisa dhu alhudund almaftuha ('another child will be sacrificed in the church's altar of open borders')

3. altadhia bitifleh ukhra fi almedhbah liajli nayl alhudund almaftuha ('the sacrifice of another child in the altar for gaining the open boarders')

4. tiflah 'ukhra liltadhia 'ala majzarat alhudund almaftuha ('another child for sacrifice on the massacre of open borders')

5. tifalah waahideh 'ukhra dhahabat dahiyat altabadul fi alhudund almaftuha ('another female child gone as a victim for exchange in the open borders') 


\section{6. hia mujarad tifl akhar salabahu almuhajiruun ghyr alshar'eiunn hayatahu}

('She is only another child deprived of its life by illegal immigrants')

In $\# 1$, the student created another unacceptable metaphor by using hykl ('temple'). In $\# 2$, \#3, \#4, and \#5, the students did not understand the SL metaphor, and in addition to misinterpreting it they also produced unidiomatic sentences in the TL. One of the students did not comprehend its meaning in the SL and failed to translate it altogether. Another student opted to paraphrase the metaphor and translated it as in \#6 above. This paraphrase sacrificed the powerful dramatic effect that the metaphor intended to create by persuading the public that borders need to be closed to immigrants. Since this metaphor is an original one, the students had to decide whether to provide a literal translation of it, reduce it to its sense, or modify the SL metaphor. From the above examples, one can see that the students used all three translation strategies. Since this is an original metaphor used by a US presidential candidate and it is not yet commonly used, rewriting it to suit the TL audience would have been a better choice than creating a new metaphor in Arabic by translating it literally. Therefore, reducing the metaphor to its sense as done in \#6 was the best option. Another difficult metaphor for students was the one used in (M6).

M6. "Before she announced her candidacy for president, Republican leaders described her-and I am quoting now—as 'very impressive.' [...] but then when it was politically expedient, those same Republicans began tearing her down."

(Barack Obama's last campaign speech for Hillary Clinton, Philadelphia, November 8th, 2016)

The phrasal verb 'tear down' meaning dismantle or disassemble is used metaphorically to expose how the Republicans started to vilify and excoriate Hillary Clinton when she started running for presidency. The source domain of this conventional conceptual metaphor is a strong foundation or structure to which Hillary Clinton is compared. The correlation between the source and target domains is strength or sturdiness. What Obama was trying to explain with this metaphor is that the Republicans tried to damage Clinton's image and reputation as a skilled or experienced politician as if tearing down a sturdy structure. Five students translated the sentence with the phrasal verb (tear her down) as qamuu bitadmiriba ('they destroyed her') and one student used qamuu bitabtimiba ('they smashed her'). Seven more students translated the metaphor as qamuu bi intiqadiha ('they criticised her') or bada hu'la' bitashwibiha ('they started to distort her') or bada'a nafs aljumburiiyn bitajribiha ('the same Republicans began to wound her'). In all these renditions, the students used a different vehicle than that used in the SL, although some are awkward in the TL and do not capture the meaning of the SL metaphor. Furthermore, two students translated the metaphor by finding a corresponding verb in Arabic that would capture the meaning of the English verb 'tear' but not the phrasal verb 'tear down' namely qamuu bitamziqiha ('they tore her'). Such a translation does not capture the meaning of the metaphor. Another student rendered it as bada'a ba 'adha aljumburiuwn bitahshimiha ('some Republicans started to shatter her'), thus rendering it as a different metaphor in Arabic with a different meaning. One student decided to use a metaphor that is frequently used in Arabic, but does not render the phrasal verb in the SL accurately: qamuu bitamziqiha 'irabaan 'irabaan ('they tore her to pieces'). This rendition 
was the most accurate and stylistically acceptable in Arabic. Four other students opted for a paraphrase of the metaphor because they were unable to find an equivalent structure in Arabic. This is illustrated in the following examples:

\section{1. bada'a aljumburiuwn nafshum yabbitun tumuhaha \\ ('the Republicans themselves started to frustrate her ambitions') \\ 2. bada'a ha'ula' aljumburiuwn dhatubum fi al'iitahati biha \\ ('these same Republicans started to overthrow her')}

3. bada'a ha'ula' fi isqatiha

('they started to cause her downfall')

4. qamuu nafs aljumburiiyn bimuharabatiha

('the same Republicans started to fight her')

These examples show that students tried to paraphrase the metaphor, but failed to produce accurate renditions of the SL metaphor and its intended effect. These different translations show that when the ST has a metaphor that sounds easy to manage but has no equivalent in the TL, students tend to produce structures that do not convey the meaning of the SL metaphor accurately. The most suitable approach in such a case is to find a metaphor in the TL that does not sacrifice the meaning of the SL metaphor and is an acceptable substitute for the TL audience. A paraphrase of the original metaphor is another choice. The four paraphrases produced by the students were, however, inaccurate translations of the ST and showed that the students did not thoroughly understand the meaning of the SL conceptual metaphor. Hence, the majority of the translations were either inaccurate or low-quality translations.

\subsubsection{Category C: Lack of Transfer of Topic, Vehicle and Grounds}

In this group, there is a lack of transfer of any sort between the SL and TL in terms of topic, vehicle, and grounds. The metaphors in the SL seem to pose a more serious challenge to the student translators than the previous ones. In some cases, the metaphors comprised terms referring to plants or flowers to describe humans in ways not common in the TL. Some metaphors are culturally or ecologically determined; for example, in Britain, where sunshine is rare, it is common to use the proverb 'make hay while the sun shines'; on the other hand, in the Arabian Peninsula where wind is a rare occasion, especially in the scorching months of the summer, it is common to use a corresponding proverb iidha habbat riahika fa'ightanamba ('When your wind blows, take advantage of it.'). In this case, two different vehicles are used, yet the same sense is maintained. The following metaphor (M7) which is a cultural one (Kövecses 2005) caused problems for the students. Despite the fact that all students were able to recognise this non-lexicalised metaphor, most of their translations failed to render it properly.

M7. "We have a stock market that is so bloated. Be careful of a bubble because what you've seen in the past might be small potatoes compared to what happens. So, be very, very careful."

(Donald Trump's remarks announcing his candidacy for president during a rally at his Trump Tower in New York City, June 16th, 2015) 
'Small potatoes' is a popular metaphorical figure of speech in Western culture and is used to indicate the triviality or insignificance of a matter. In this example, a conceptual metaphor (important is big and unimportant is small) is invoked. Trump warns his supporters about an economic bubble that will have such serious repercussions that what they saw in the past will be considered figuratively as small potatoes in comparison. 'Small potatoes' has no corresponding equivalent in Arabic. Students thus had to find suitable strategies to translate this idiomatic expression into the TL to preserve its meaning. Five students decided to translate the metaphor literally, rendering it as qatea' saghirah min albatata (small pieces of potatoes) or as habbat batata saghirah (small potatoes), and hence failing to understand the meaning of this expression in the SL and therefore failing to find a culturally acceptable metaphor in the TL. The literal translation is not an acceptable strategy, since it does not convey the meaning of the SL metaphor in the TL. The following are some other translations that the students produced:

1. la y'aedu 'an yakun mujarrad safasif muqaranatan bima sayahduth $f$ almustaqbal ('it is no more than just small things in comparison to what will happen in the future')

2. 'inna dhalika hua mujarrad fuqa' a saghiira ('that is just a small bubble')

3. qad yakuun amran basytan/saghyran/taafihan muqaranatan bima sayahduth ('this may be a simple/small /trivial issue compared to what will happen')

4. lays 'illaa juzayy'at basita bima yumkin 'an yahsul ('are only simple molecules of what could happen')

5. ma ra'aytubu saabiqan la wa lan yuqaranu bima sataraabu fi almustaqbal ('what I saw before can and will not be compared with what you will see in the future')

This metaphor is similar to other metaphors such as ('it's peanuts', 'it's pennies' etc.); however, if the same vehicle is maintained in the TT, it loses both its metaphorical nature and the intended message, since this expression is not used to express the idea of triviality in Arabic. Accordingly, when some students used the strategy of maintaining the metaphorical vehicle by using qatea saghirah min albatata ('small pieces of potato'), they failed to preserve the metaphorical nature of the phrase in the TL and simultaneously failed to convey the intended message, since the phrase qatea 'saghirah min albatata ('small pieces of potato') cannot be interpreted by Arabic native speakers to mean 'a trivial matter'. In another example, a student produced a similar translation to the previous one with slightly different words: habbat batata saghira ('small potatoes'). This shows that when there is no direct equivalent metaphor in the target language, some of the translators may erroneously opt for a literal translation of the source metaphor without considering the acceptability of the literal translation in the TL. Doing so, the metaphorical nature of the source text is often lost entirely and the intended message is completely obscured.

In \#1, the student used a vehicle from the TL which is not equivalent to the one used in the SL, safasif al'umuur ('trivial things'); however, this translation preserves the figurative nature of the SL metaphor in Arabic and produces an idiomatic structure in the TL that is 
also stylistically acceptable. In translation \#2, the student used the already present 'economic bubble' metaphor, fuqa 'a (bubble), to capture the bloatedness of the market, but removed the expression ('small potatoes') entirely without any substitution. A third strategy used by nine students was to reduce the SL metaphor to its sense. The translations that they produced in \#3 such as shay'an saghiiran, shay'an taafihan, shay'an dhu ta'thiir basiit ('a little thing', 'a trivial thing', 'something with a little impact') ignored the vehicle of the source metaphor, but preserved its sense. The rendition in $\# 4$ is not an acceptable usage in Arabic, and the rendition in \#5 also omits the source text metaphor and paraphrases the meaning of the sentence. The translation approach in \#1 and \#3 was the most acceptable in this case.

The next example (M8) is a similar one:

M8. "We also have to be honest about the fact that not everyone who seeks to join our country will be able to successfully assimilate. Sometimes it's just not going to work out. It's our right as a sovereign nation to choose immigrants that we think are the likeliest to thrive and flourish and love us."

(Donald Trump's immigration speech, Phoenix, Arizona, August 31st, 2016)

This conceptual metaphor can be classified as a dead transparent one which uses a horticultural image that invokes the growth and development of a plant. It involves the understanding of one domain of experience, which is the immigrants' integration into the US society, in terms of a different and more concrete one that is the growth of a plant. The US soil is the nutrient for these immigrants, and it will enable them to grow if they have the potential for growth and development. When attempting to translate this excerpt, the majority of students tried hard to preserve the same words used in the SL and find proper translations for them rather than opting for a paraphrase. Eight students translated 'thrive' and 'flourish' either as yanjah ('succeed') and yazdahar ('flourish') using the present verb forms or as alnajaah ('success') and alizdihaar ('prosperity') using the noun form. Two students translated the metaphor as albuzuugh ('emergence', 'appearance' or 'rise') and alizdihaar ('prosperity') and one student as alizdihaar walinjaaz ('prosperity' and 'achievement'). Another student decided to render it as numuabum ('their growth') and najahahum ('their success'). Four students translated it as tatawur wa izdihaar albilaad ('the development and prosperity of the country') or as izdihaar wa numui albilaad ('prosperity and growth of the country'). The remaining translations were as follows:

1. nakbtaar min hum nae' taqid 'annahum murjjabiin 'akthar liyanmuu wa tazdabir hayatuhum

('we choose those who we believe have more potential to grow and their lives flourish')

2. laysa kul min yas'aa lilindhimaam ilaina sayanjah $f i$ isti' eabina ('not everyone who seeks to join us will succeed in comprehending us')

3. lana alhaqqu $f i$ ikhtiar almuhajiriin alladhiina ladayhim alqudra al'akbar $f i$ altatawur w(a)el infitah

('we have the right to choose the immigrants who have the greatest ability for development and openness') 
These different translations demonstrate the partial or total loss of the SL metaphor. While the students translated 'thrive' in a non-metaphorical expression yanjah, they rendered the second part as yazdahar ('flourish'), which is a metaphor in Arabic. However, the metaphor used in the second part is usually reserved for entities such as places, not humans. This is probably why some students opted to eliminate the metaphor completely as in \#2 and replace it with a phrase conveying the same intended meaning, sayanjah ('will succeed'). Others focused on the implied meaning concerning the expected outcome of choosing suitable immigrants and rendered it as alladhiin hum al'aqdar 'ala almusahama fi izdihaar wa numui albilaad ('those who are most capable of contributing to the growth and prosperity of the country'), where they transferred the metaphor from the immigrants to the country. It is interesting to see that in this rendition the students focused on explaining the way in which the immigrants can contribute to the development of the country, but overlooked that the metaphor is concerned with the immigrants themselves who are the contributors to its development. The best strategy in translating such a metaphor would have been creating one in the TL that would capture the figurative nature of the SL metaphor. One option would have been rendering it as yanmu ('growing' or 'to grow') and yazhir ('flowering' or 'to flower'). The most accurate and acceptable translation into Arabic is the one in \#1.

The next metaphor (M9) can be classified as a recent metaphor:

M9. "To just be grossly generalistic, you can put half of Trump's supporters into what I call the basket of deplorables. Right? They're racist, sexist, homophobic, xenophobic, Islamophobic - you name it. And unfortunately there are people like that and he has lifted them up."

(from Hillary Clinton's speech at a New York City LGBT fundraiser, Sept. 9th, 2016)

This original non-lexicalised metaphor is created in analogy with a common trope that includes the word 'basket' such as 'currency basket' or financial baskets that involve investment. It is a figure for 'group' and intends to say that the voters who support Trump are a group of deplorable people. When translating this metaphor, the students faced difficulties in rendering the second part of the metaphor ('deplorables') as it has several meanings. This metaphor apparently left two students puzzled to the extent that they did not attempt to translate it. Seven students translated it as sallat albu'asa' or sallat alba'yisuun ('basket' of 'miserables') using either the broken plural albu'asa' or the sound masculine plural albayisuun in Arabic. In Arabic, there are two types of noun plural forms: sound (regular) plurals, and broken (irregular) plurals. Masculine sound plural nouns end in the plural morpheme uun. Irregular plurals are known as jam' taksiir. These plurals constitute one of the most unusual aspects of Arabic, and they have detailed grammar and derivational rules. Two students rendered it as sallat almuthiriin lilshafaqa ('the basket of the pathetic'). Three translated it as sallat almurtha lihalihim ('basket of those of lamentable conditions') or sallat almurtha lahum ('basket of lamentables'). The rest produced the following translations:

1. sallat almustabjiniin

('the basket of condemned people')

2. sallat alfaza' $a$

('the basket of horror') 


\section{3. sallah min aldana'a}

('a basket of meanness')

4. salah min alte' asa

('a basket of misery')

5. fiat albayisiin

('the category of the wretched')

6. majmu'ah min alba'yisiin

('a group of the wretched')

The recent metaphor in Arabic sallat albu'asa' ('the basket of miserables') is an acceptable rendition, but the other translations that maintained only the first word of the SL metaphor ('basket') and failed in the translation of the word 'deplorables' led to awkward renditions not common in the TL. In all these translations, except for \#5 and \#6, the students used the word sallah or sallat (in the case of a genitive the ' $\mathrm{h}$ ' in sallah is pronounced /t/ to ease pronunciation linking it to the 'al' in the word after it) which violates the collocational and semantic rules of Arabic, as the word cannot be used in association with humans even in a structure that is a metaphor. As a result, all translations sound awkward and do not match any acceptable collocational patterns in Arabic. A better rendition would have been hifna min alba'yisiin ('a handful of miserables').

\subsection{Translation Strategies}

To overcome translation difficulties, the translators resorted to the translation strategies such as paraphrase and adaptation (see Hatim and Munday 2004, 15). The following table presents the related results.

TABLE 2. Translation strategies.

\begin{tabular}{|l|l|l|l|l|}
\hline Metaphors & $\begin{array}{l}\text { Types of } \\
\text { metaphor }\end{array}$ & $\begin{array}{l}\text { Recogni- } \\
\text { tion } \\
\text { task in \% }\end{array}$ & $\begin{array}{l}\text { Translation strategies } \\
\text { used by students }\end{array}$ & $\begin{array}{l}\text { \% of accept- } \\
\text { able transla- } \\
\text { tions }\end{array}$ \\
\hline M1 & $\begin{array}{l}\text { Conventional- } \\
\text { ised transpar- } \\
\text { ent }\end{array}$ & $90 \%$ & $\begin{array}{l}\text { Direct transfer } \\
\text { Replacement w/ idiom in TL L } \\
\text { Deletion }\end{array}$ & $95 \%$ \\
\hline M2 & $\begin{array}{l}\text { Convention- } \\
\text { alised recent } \\
\text { cliché }\end{array}$ & $10 \%$ & Direct transfer & $90 \%$ \\
\hline M3 & $\begin{array}{l}\text { Conceptual/ } \\
\text { transparent }\end{array}$ & $85 \%$ & Direct transfer & $95 \%$ \\
\hline M4 & $\begin{array}{l}\text { Conceptual/ } \\
\text { transparent }\end{array}$ & $60 \%$ & $\begin{array}{l}\text { Substitution with an accepta- } \\
\text { ble TL collocational structure } \\
\text { that partially preserves the SL } \\
\text { metaphor }\end{array}$ & $35 \%$ \\
\hline
\end{tabular}




\begin{tabular}{|l|l|l|l|l|}
\hline M5 & Original & $70 \%$ & $\begin{array}{l}\text { Substitution of the SL meta- } \\
\text { phor with a new metaphor in } \\
\text { the TL } \\
\text { Paraphrase } \\
\text { Reduction to sense }\end{array}$ & $5 \%$ \\
\hline M6 & $\begin{array}{l}\text { Conceptual } \\
\text { (phrasal verb) }\end{array}$ & $95 \%$ & $\begin{array}{l}\text { Substitution } \\
\text { Paraphrase }\end{array}$ & $5 \%$ \\
\hline M7 & $\begin{array}{l}\text { Concep- } \\
\text { tual metaphor/ } \\
\text { idiom }\end{array}$ & $100 \%$ & $\begin{array}{l}\text { Literal translation } \\
\text { Reduction to sense } \\
\text { Substitution } \\
\text { Deletion }\end{array}$ & $50 \%$ \\
\hline M8 & $\begin{array}{l}\text { Dead transpar- } \\
\text { ent }\end{array}$ & $65 \%$ & $\begin{array}{l}\text { Direct transfer } \\
\text { Deletion } \\
\text { Substitution }\end{array}$ & $5 \%$ \\
\hline M9 & $\begin{array}{l}\text { Original non- } \\
\text { lexicalised }\end{array}$ & $95 \%$ & $\begin{array}{l}\text { Direct transfer } \\
\text { Substitution } \\
\text { Reduction to sense }\end{array}$ & $0 \%$ \\
\hline
\end{tabular}

As the results show, whenever there was no commonly known equivalent form in the TL the students faced serious challenges because maintaining the metaphoric structure in their renditions would obscure the intended message and create structural and collocational patterns that violate the acceptable norms in the TL. Various translation strategies were thus employed to deal with such cases.

\section{Conclusion and Recommendations}

This study investigated the linguistic, rhetorical, and cultural problems Omani undergraduate translation students encountered in recognising, understanding, and translating metaphors used in the campaign speeches delivered by Barack Obama, Donald Trump, and Hillary Clinton during the 2016 US presidential campaign, and examined what strategies students utilised to translate metaphorical structures into Arabic. The findings show that in eight out of nine cases, more than $60 \%$ of the students recognised the metaphors in various texts; however, in only three cases were the majority of students able to produce a linguistically and rhetorically acceptable rendition of the metaphoric structure in the TL that preserved the SL metaphor and/or its meaning. Hence, the students' inability to translate metaphors properly cannot not be attributed to a lack of ability to identify the different metaphors. This is a very important finding with significant implications for translator-trainers. Only in the case of (M2) did the students demonstrate significant difficulty in recognising the metaphor because it has been naturalised in both the SL and TL. The cases that posed a considerable challenge to students were a recent cliché metaphor, a conceptual transparent metaphor, an original metaphor, and a dead transparent metaphor.

With regard to the process of translating metaphoric structures, the study has found that some students consciously adopted different strategies to translating metaphors and others just approached the ST without any discernible consideration of appropriate translation 
strategies. In the majority of cases, the students were not able to produce rhetorically and linguistically acceptable translations of the sentence structures that contained metaphors. In metaphors where there is a direct transfer (Category A) the students produced different renditions that mostly maintained the metaphoric nature of the ST and the ideational content of the metaphor, hence achieving direct equivalence (Molina and Albir 2002). In these cases, the students maintained all components of the metaphor: topic, vehicle, and grounds. As for Category B (partial transfer of metaphor parts), the students did not use all three components of the metaphor, yet tried to maintain the metaphoric nature of the text by using a variety of translation strategies. Their renditions were, however, mostly unacceptable. In Category C (lack of transfer of metaphor parts), most students understood the meanings of the ST metaphors, but were not able to maintain the metaphors in the TL and mostly produced paraphrases and adaptations that reduced the metaphors to sense. In Categories B and $\mathrm{C}$, the majority of students faced serious problems in producing acceptable translations. Those students who were aware of the rhetorical and cultural dimensions of the metaphors within the context of political discourse tried to preserve them, but in many cases failed to produce collocational structures that are acceptable to the TL audience and would preserve the meaning and rhetorical effect of the metaphor. Whenever there was no commonly known equivalent form in the TL, the students faced serious challenges because maintaining the metaphoric structure in their renditions would obscure the intended message and create structural and collocational patterns that violate the acceptable norms in the TL. To overcome such difficulties, they resorted to translation strategies such as paraphrasing and adaptation (see Table 2 above).

The findings of this research are also indicative of the extent of students' competence in both the source and target languages and their ability to grasp the intended meaning, purpose, and significance of tropes used in political discourse. Translating political texts can involve special language that has no direct and clear rendition, because translation is not only a technical process, but also involves the understanding of the SL and TL cultural contexts in addition to the political situation and shades of meaning the speaker intends to convey. Inexperienced translators may render these texts inaccurately, especially when they contain unfamiliar or unique metaphors. Hence, it is imperative that translation trainees be taught to first identify the metaphors, grasp their meanings, and understand their usage within their contexts; secondly, they need to be trained in deciding what strategies would be most effective to translate various types of metaphors into the TL.

Translation programs traditionally offer courses in translation theory and technical translation. What is often lacking is training in practical translation. Students thus graduate without much practical experience in translating a variety of texts, such as political texts. They have also no specific training in recognising and translating rhetorical devices, figures of speech, and other stylistic conventions that are very common in such texts. It is thus recommended that students be trained in a more targeted manner to be able to approach stylistically complex texts such as political discourse that naturally contains many tropes. What the researchers also noticed is that students lack proper command of standard Arabic and in-depth cultural and linguistic knowledge of both English and Arabic. Based on these findings, the researchers recommend that more 
practical translation courses be offered, more stylistics taught to familiarise students with rhetorical devices and figures of speech, and more targeted courses be given to train students how to refine their translation skills and expand their cultural knowledge and awareness of both the source and target languages.

\section{References}

Aldanani, Mansour. 2018. "Translating Metaphorical Expressions in Political Discourse: A Comparative Conceptual Study (English-Arabic).” AWEJ for Translation \& Literary Studies 2 (4): 144-51. http:// dx.doi.org/10.2139/ssrn.3276443.

Al-Harahsheh, Ahmad M. 2013. "The Translatability of Figures of Speech in Khalid Mashaal's Political Speeches: A Critical Discourse Analysis.” International Journal of English Linguistics 3 (3): 100-114. https://doi.org/0.5539/ijel.v3n3p100.

Al-Hasnawi, Ali R. 2007. “A Cognitive Approach to Translating Metaphors.” Translation Journal 11 (3). https://translationjournal.net/journal/41 metaphor.htm.

Ateeg, Najla'a, and Abdulaziz Al-Tamimi. 2014. "The Translatability of Emotive Expressions in Islamic Texts from English into Arabic." Andalusia Journal for the Humanities and Social Sciences 3 (8): 23-51.

Bojović, Brankica. 2014. "Strategies of Metaphor Translation." ELTA Journal 2 (2): 74-81.

Dagut, Menachem B. 1976. “Can 'Metaphor' Be Translated?” Babel 22 (1): 21-33.

Dickins, James. 2005. “Two Models for Metaphor Translation.” Target 17 (2): 227-73. https://doi. org/10.1075/target.17.2.03dic.

Dickins, James, Sándor Hervey, and Ian Higgins. 2002. Thinking Arabic Translation: A Course in Translation Method: Arabic to English. New York: Routledge. https://doi.org/10.4324/9781315012650.

Farhan, Zuhair G., and Yasir A. Taha. 2006. "A Stylistic Emotive Approach to English-Arabic Literary Translation." Adab Al-Rafidayn 43: 43-60.

Ghazala, Hassan. 2012. "Translating the Metaphor: A Cognitive-Stylistic Conceptualization (EnglishArabic).” World Journal of English Language 2 (4): 57-68. https://doi.org/10.5430/wjel.v2n4p57.

Gonzálvez-García, Francisco, María Sandra Peña Cervel, and Lorena Pérez Hernández. 2013. Metaphor and Metonymy Revisited Beyond the Contemporary Theory of Metaphor: Recent Developments and Applications. Philadelphia: John Benjamins.

Hampe, Beate, ed. 2017. Metaphor: Embodied Cognition and Discourse. Cambridge: Cambridge University Press.

Hatim, Basil, and Jeremy Munday. 2004. Translation: An Advanced Resource Book. New York: Routledge. Jaber, In’am. 2008. “Translating Metaphoric Expressions: Translating Culture.” Journal of College of Education for Women 19 (2). https://www.iasj.net/iasj?func=fulltext\&aId=11971.

Kövecses, Zoltan. 2005. Metaphor in Culture. Universality and Variation. Cambridge: Cambridge University Press.

—. 2010. Metaphor: A Practical Introduction. Oxford: Oxford University Press.

-. 2015. Where Metaphors Come From: Reconsidering Context in Metaphor. Oxford: Oxford University Press.

—. 2016. "Conceptual Metaphor Theory." In The Routledge Handbook of Metaphor and Language, edited by Elena Semino and Zsófia Demjén, 13-27. Oxon and New York: Routledge.

Lakoff, George, and Mark Johnson. 1980. Metaphors We Live By. Chicago: University of Chicago Press.

—. 1999. Philosophy in the Flesh: The Embodied Mind and Its Challenge to Western Thought. New York: Basic Books.

- 2002. Moral Politics: How Liberals and Conservatives Think, 2nd ed. Chicago: University of Chicago Press. https://doi.org/10.7208/chicago/9780226471006.001.0001.

- 2008. "The Neural Theory of Metaphor." In The Cambridge Handbook of Metaphor and Thought, edited by Raymond W. Gibbs, Jr., 17-38. Cambridge: Cambridge University Press. https://doi.org/10.1017/ CBO9780511816802.003. 
Mandelblit, Neli. 1995. "The Cognitive View of Metaphor and Its Implications for Translation Theory." Translation and Meaning 3: 483-95.

Mansoor, Khalid. 2017. "The Concept of Metaphor in the English-Arabic Translation.” Professional Communication and Translation Studies 10: 155-62.

Mason, Kirsten. 1982. "Metaphor and Translation." Babel: International Journal of Translation 28 (3): 140-49. https://doi.org/10.1075/babel.28.3.05mas.

Molina, Lucía, and Amparo Hurtado Albir. 2002. "Translation Techniques Revisited: A Dynamic and Functionalist Approach.” Meta 47 (4): 498-512. https://doi.org/10.7202/008033ar.

Nader, Maria. 2014. "Translating Metaphor in Economic Newspaper Articles: A Case Study of the Translation of Conceptual and Linguistic Metaphors from English into Arabic." New Voices in Translation Studies 11: i-ii.

Newmark, Peter. 1988a. A Textbook of Translation. London: Prentice Hall.

-. 1988b. Approaches to Translation. Oxford: Pergamon Press.

Onuf, Nicholas. 2013. Making Sense, Making Worlds: Constructivism in Social Theory and International Relations. New York: Routledge. https://doi.org/10.4324/9780203096710.

Paprotté, Wolf, and René Dirven. 1985. The Ubiquity of Metaphor: Metaphor in Language and Thought. Philadelphia: John Benjamins.

Ramadan Shunnaq, Susanne, Hassan Shuqair, and Adel Abu-Radwan. 2018. "The Hurdle of Rhetoric: An Analytical Study of Omani Students' Translation of Political Speech.” Onomázein 40: 139-158. https://doi.org/10.7764/onomazein.40.09.

Shunnaq, Abdullah. 1993. "Lexical Incongruence in Arabic-English Translation due to Emotiveness in Arabic.” Turjuman 2 (2): 37-63.

van den Broeck, Raymond. 1981. "The Limits of Translatability Exemplified by Metaphor Translation.” Poetics Today 2: 73-87.

Wilss, Wolfram. 1996. Knowledge and Skills in Translator Behavior. Philadelphia: John Benjamins. https:// doi.org/10.1075/btl.15. 